\title{
Safety Studies of DpNPV (Diaphania pulverulentalis Nuclearpolyhedrosis Virus) Suspension and its Formulation on Non-Target Organisms in Mulberry Ecosystem
}

\author{
S. Prabhu ${ }^{1}$, C.A. Mahalingam ${ }^{2}$ and S.V. Krishnamoorthy ${ }^{1}$ \\ ${ }^{1}$ Department of Sericulture, Forest College and Research Institute, Tamil Nadu Agricultural \\ University, Mettupalayam-641 301, India \\ ${ }^{2}$ Department of Agricultural Entomology, Tamil Nadu Agricultural University, \\ Coimbatore- 641 003, India \\ *Corresponding author:
}

\section{A B S T R A C T}

Laboratory studies were carried out to explore the potential of Diaphania pulverulentalis (Hampson.) nucleopolyhedrosis virus $(D p N P V)$ suspension and its formulations against non-target organisms viz., Trichogramma chilonis Ishii, Chrysoper lacarnea (Stephens), Bombyx mori (L.), Apiscerena indica (Fab.), Apis mellifera (L.) and Apis florea. The per cent parasitization, adult emergence of $T$. chilonis exposed to $D p N P V$ suspension did not differ significantly with that of $D p N P V$ formulations and control, while, the per cent parasitization and adult emergence were significantly lower in dichlorvos treated eggs. $C$. carnea exposed to $D p \mathrm{NPV}$ suspension showed no adverse effects on per cent hatchability, larval period, per cent pupation, pupal period, adult emergence, adult longevity, total life cycle and grub mortality in comparison with $D p N P V$ formulations and control. Whereas, dichlorvos was found to be hazardous compared to NPV and control. The larval weight of third, fourth and fifth instar of B. mori, per cent larval mortality, pupation, pupal period, adult emergence cocoon weight and shell weight exhibited no significant differences between the virus treated and control indicating the safety of the $D p N P V$ suspension and its formulation. The survival period of bees in virus treatments was on par with control, while the survival period of bees was significantly low (1-2 days only) in dichlorvos. Results indicated no evidence of infection or other pathological manifestations in the tissues of bees.

\section{Introduction}

Regular usage of toxic chemicals in mulberry garden to control the pests cause pollution and are detrimental to human beings and beneficial organisms including silkworms. Further, the pests develop resistance to the chemical insecticides with indiscriminate use and result in sudden outbreak. In view of these, pest management using non-chemical methods have gained importance including biological control. Among bio control agents, baculovirus are very important as they are arthropod specific pathogens. Higher host specificity and amenability for formulation as that of chemical pesticides make baculoviruses particularly attractive as biological control agents (Dent and Jenkins, 2000). The Baculoviridae is a promising family of viruses that might provide active 
agents for successful biopesticides because members of two groups, the nucleo polyhedroviruses (NPVs) and the granulosis viruses $(\mathrm{GV})$, infect many important insect pests (Blissard et al., 2000; Fauquet et al., 2004). NPV based biopesticides, along with the use of feeding stimulants that encourage phytophagous larvae to consume foliage contaminated with viral occlusion bodies (OBs) could result in an increased prevalence of infection and improved pest control (Lasa et al., 2007).

The biopesticidal potential of baculoviruses has not been completely realized due to lack of information about particular properties of the virus that are involved in virulence. Considerable effort has been made to understand more about the molecular biology of baculoviruses and how they interact with host insect at the molecular level with the expectation that this information would aid in improving virus efficacy (Burand and Park, 1992).

One of the major drawbacks of using entomo pathogens as biopesticides is their lack of persistence in the environment. Their infectivity is affected by environmental factors such as sunlight radiation, temperature, moisture and $\mathrm{pH}$. These factors limit the field application and subsequent commercialization of many entomopathogens, including baculoviruses (Rabindra and Jayaraj, 2005).

Baculoviruses, particularly, nucleopolyhedro viruses (NPV), are deleteriously affected by sunlight radiation (Priyadharshini, 2009). Formulation of NPV based biopesticides could improve their efficacy to achieve acceptable levels of pest control with low doses of pathogen, representing an important reduction in the cost of each application (Lasa et al., 2009). Inactivation of viruses on foliage has been a major problem in the development of formulations of viral insecticides for use in insect management systems. Use of adjuvants has been found to increase the persistence of the virus in the environment (Mehrvar et al., 2008). The incorporation of adjuvants with microbial insecticides to preserve the virus activity is commonly followed (Muthuswami et al., 1994; Rabindra and Jayaraj, 1995). This is usually attributed to the improved field persistence of the virus due to increased consumption of the virus by the pest (Arivudainambi et al., 2000; Amin et al., 2005). Being obligate pathogens, viruses cannot multiply outside the environment of the host insect and have to remain in a viable state before they are ingested by the host insect.

A number of materials tested for use as adjuvants to protect the baculoviruses from sunlight inactivation, enhance activation over the foliage and effective intake by lepidopteran larvae (Sajap et al., 2007). Tinopal, sugars such as sucrose, fructose and sorbitol have been proved to increase the efficacy of NPV formulation (Sajap et al., 2009).

The use of pesticide on mulberry is discouraged due to its broad spectrum nature and therefore, could have a great fatal effect on the predators of leaf webber. Though pesticides could give quick relief to the pest problem owing to their knock down effect, these strategies cannot be employed on the pest when the silkworm rearing is under progress, because of detrimental effect of the chemical on silkworm.

Baculoviruses are used as an excellent biological insecticide due to its restricted host specificity and non-infectivity to beneficial insects, with this background the present investigation on the pathogenicity, development of formulation and its safety to non-target organisms was carried out. 


\section{Materials and Methods}

The safety of $D p$ NPV suspension and its formulations to the following non-target organisms viz., Egg parasitoidTrichogramma chilonis Ishii, Predator Chrysoperla carnea (Stephens), Silkworm Bombyx mori (L.), Honey bees species like Apis cerana indica (Fab.), Apis mellifera (L.) and Apis florea were tested with the following treatmentsviz.,T1-DpNPV* + Starch $10 \%$ + Tinopal $0.2 \%$ + Tween $801 \%$, T2- $D p \mathrm{NPV}^{*}+$ Sucrose $10 \%+$ Tinopal $0.2 \%$ + Tween80 1\%, T3- DpNPV* + Glycerol $10 \%$ + Tinopal $0.2 \%$ + Tween80 1\%, T4DpNPV @ 1x109 POBs/ml, T5- Dichlorvos @ $0.2 \mathrm{ml} / \mathrm{lit}$ and T6- Control with water spray. The dosage of virus which used in the treatments is *DpNPV @ $1 \times 10^{9} \mathrm{POBs} / \mathrm{ml}$, the above treatments with five replications included for safety tests.

\section{Trichogramma chilonis}

Freshly laid $D$. pulverulentalis eggs on cloth strips were used for the study of parasitism and parasitoid emergence. Each cloth strip was cut into pieces of size $2 \times 2 \mathrm{~cm}$ with egg density ca. 200 in five replicates for each treatment. The pieces were stapled firmly to $144 \mathrm{gsm}$ paper and exposed to UV for $20 \mathrm{~min}$ to kill the developing embryo. The treatments were applied on the egg cards with the help of an atomizer using a spray fluid volume of 2 $\mathrm{ml}$. The cards were allowed to shade-dry for 30 min and transferred to poly bags.

Newly emerged parasitoids of $T$. chilonis were anaesthetized with $\mathrm{CO}_{2}$ and released @ 50 per treatment on the treated egg cards in polybags. Parasitization was allowed for two days after which the egg cards were transferred to fresh polybags. Observations on per cent parasitism and parasitoid emergence were recorded. Parasitoids that emerged in the respective treatments in the first generation were counted by anaesthetizing with $\mathrm{CO}_{2}$ and utilized for second generation studies and the procedure was repeated.

\section{Chrysoperla carnea}

Dry film method was adopted to access the $D p$ NPV to $C$. carnea, though the virus and dichlorvos treated $D$. pulverulentaliseggs previously exposed to UV, C. carnea first instar grubs emerging from previously treated C. carnea eggs were released @ 1:100. Each treatment had 50 grubs in five replicates. The grubs were confined in test tubes covered with muslin cloth and secured tightly with a rubber band. The grubs were daily fed with treated one day old $D$. pulverulentalis eggs till pupation. After pupation, they were separated and transferred to plastic jars $(20 \mathrm{~cm} \mathrm{ht}$, and 8 $\mathrm{cm}$ dia) for adult emergence. The adults were allowed in plastic jars and fed with a mixture of honey, protein hydrolysate, fructose, yeast and water in the ratio $1: 1: 1: 1$. Observations on grub mortality, per cent pupation, hatching and adult longevity were recorded.

\section{Bombyx mori}

Larvae of III, IV, V instars of double hybrid $\mathrm{DH}_{1}$ silkworm were fed with chopped mulberry leaves treated with $D p N P V$ suspension @ $1 \times 10^{9} \quad \mathrm{POBs} / \mathrm{ml} \quad D p \mathrm{NPV}$ formulation $\left(D p \mathrm{NPV}^{*}+\right.$ Starch10\%+ Tinopal $0.2 \%+$ Tween $801 \%$ ) for $24 \mathrm{~h}$. Subsequently, fresh untreated leaf bits were provided at $12 \mathrm{~h}$ interval. Control with water spray was maintained. Each treatment was replicated five times with 20 larvae. A check without virus was maintained by feeding the larvae with leaves dipped in distilled water. Observations on the weight of larvae, mortality of larvae, fresh weight of cocoon, shell weight and adult emergence were recorded.

\section{Honey bees}

Safety of $D p$ NPV was tested for honey bees viz., A. ceranaindica, A. mellifera and A. 
florea. Day old worker bees were caged $(30 \times 30 \times 30 \mathrm{~cm})$ at the rate of 30 without the queen and fed with 50 per cent sucrose solution containing $D p N P V$ virus @ $1 \times 10^{9}$ $\mathrm{POB} / \mathrm{ml}$. Similarly, different $D p N P V$ formulations and dichlorvos $0.2 \%$ were mixed in 50 per cent sucrose solution and fed for 24 h. Afterwards, 50 per cent sucrose alone was provided till the bees died. In control, bees were fed with sucrose solution alone. The mortality of bees was observed daily until all the bees died.

\section{Results and Discussion}

The results of the experiments on safety of $D p N P V$ suspension and its formulation to non- target organisms, laboratory experiments conducted to assess the bioefficacy of different $D p N P V$ formulations against mulberry leaf webber $-D$. pulverulentalis in mulberry and safety to non- target organisms are presented below.

\section{Safety tests on non-target organisms}

\section{T. chilonis}

In the present study, $D p N P V$ was found to be safe to $T$. chilonis when it was treated on egg, further it did not show any deleterious effect on parasitization and parasitoid emergence (Fig. 1). HaGV and PxGV were found to be safe to T. chilonis (Kuppusamy, 1994; Sairabanu, 2000). Safety of baculoviruses to $T$. chilonis was reported earlier by Ethiraju (1986), Muthiah and Rabindra (1991), Maheshbabu (1991) and Geetha (1997).

$H a \mathrm{NPV}$ was not found to be pathogenic to $T$. chilonis (Balasubramanian et al., 2001). Boomathi et al., (2005) reported that the use of HaNPV@ @ $3 \times 10^{12}$ POBs ha ${ }^{-1}$ and Spicturin (commercial Bt formulation) @ $2.0 \mathrm{~L} \mathrm{ha}^{-1}$ found to be safe to the egg parasitoid (T. chilonis). In laboratory studies, a UV- selected strain of $\mathrm{HaNPV}$ was found to be safer to $T$. chilonis, Chrysoper lacarnea (Stephen), honeybee and Bombyx mori L. (Jeyarani et al., 2008).

Reduction of $H$. armigera parasitoid, Campoletis chloridiae Uchida and other natural enemies was lower in the $\mathrm{HaNPV}$ sprayed plots (3\%) as compared to 60 per cent reduction in the endosulfan treated plots in chickpea.HaNPV@ 250 LE ha ${ }^{-1}$ application on chickpea resulted in a reduction of aerial and soil inhabiting natural enemies by 15 and 22 per cent respectively, over the control plots, while the reduction in the endosulfan sprayed plots was 52.4 and 63.1 per cent, respectively (Ranga Rao et al., 2008).

\section{C. carnea}

In the present study, $D p N P V$ was found to be safe to $C$. carnea with reference to pupation, adult emergence and total life cycle (Table 1 and Fig. 2). Safety of baculoviruses to $C$. carnea has been reported by many workers in $\mathrm{HaGV}$ (Kuppusamy, 1994) and PxGV (Sairabanu, 2000) to C. carnea. Safety of other baculoviruses to $C$. carnea has been reported by many workers (Maheshbabu, 1991; Heinz et al., 1995; Thennarasan, 1997; Geetha, 1997; Subramanian, 1998).

However, exposure to endosulfan treated eggs caused significant variation in the biological parameters of $C$. carnea. It could be inferred that NPV is compatible with C. carnea and could be utilized in IPM.

\section{B. mori}

In the present studies, application of $D p N P V$ and its formulations was found to be safe to B. mori. The larval and cocoon parameters were not affected by the virus treatments (Table 2). Application of $D p N P V$ had no adverse effects on $B$. mori. In earlier 
investigations, the granulosis viruses of Chiloinfus catellus, Chilosaccharipha gusindicus, Adalia bipunctata, Helicoverpa armigera and Spodoptera exigua NPV were not infective to B. mori, $T$. chilonisand $C$. carnea (Easwaramoorthy and Jayaraj, 1988; Chen et al.,
1992; Kuppusamy, 1994; Kondo et al., 1994). Mahiba Helen et al., (2012) proved the safety of $H p \mathrm{NPV}$ to $B$. mori larvae. This indicated that the viruses could be effectively utilized in mulberry ecosystem where sericulture is practiced.

Table.1 Selective toxicity of D $p$ NPV and its formulation to adults of Chrysoperla carnea

\begin{tabular}{|c|c|c|c|c|}
\hline \multirow[b]{2}{*}{ S.No } & \multirow{2}{*}{ Treatments } & \multicolumn{3}{|c|}{ Mortality (\%) } \\
\hline & & 12 HAT & 24 HAT & 48 HAT \\
\hline 1. & $\begin{array}{l}D p N P V *+\text { Starch } 10 \%+\text { Tinopal } 0.2 \%+ \\
\text { Tween } 801 \%\end{array}$ & $\begin{array}{c}0.00 \\
(0.19)^{\mathrm{a}} \\
\end{array}$ & $\begin{array}{c}3.33 \\
(10.25)^{b}\end{array}$ & $\begin{array}{c}3.33 \\
(10.25)^{\mathrm{a}} \\
\end{array}$ \\
\hline 2. & $\begin{array}{l}\text { DpNPV } *+\text { Sucrose } 10 \%+\text { Tinopal } 0.2 \% \\
+ \text { Tween } 801 \%\end{array}$ & $\begin{array}{c}6.67 \\
(14.70)^{b}\end{array}$ & $\begin{array}{c}6.67 \\
(14.70)^{c}\end{array}$ & $\begin{array}{c}6.67 \\
(14.70)^{b}\end{array}$ \\
\hline 3. & $\begin{array}{l}D p \mathrm{NPV}^{*}+\text { Glycerol + Tinopal } 0.2 \% \\
+ \text { Tween } 801 \%\end{array}$ & $\begin{array}{c}6.67 \\
(14.96)^{b}\end{array}$ & $\begin{array}{c}10.00 \\
(18.43)^{\mathrm{c}}\end{array}$ & $\begin{array}{c}13.33 \\
(21.41)^{\mathrm{c}}\end{array}$ \\
\hline 4. & $D p \mathrm{NPV}^{*}$ & $\begin{array}{c}13.33 \\
(21.39)^{\mathrm{c}}\end{array}$ & $\begin{array}{c}33.33 \\
(35.26)^{\mathrm{d}}\end{array}$ & $\begin{array}{c}36.67 \\
(37.27)^{d}\end{array}$ \\
\hline 5. & Dichlorvos76EC $0.2 \%$ & $\begin{array}{c}33.33 \\
(35.26)^{d}\end{array}$ & $\begin{array}{c}56.67 \\
(48.83)^{\mathrm{e}}\end{array}$ & $\begin{array}{c}63.33 \\
(52.73)^{\mathrm{e}}\end{array}$ \\
\hline 6. & Untreated check & $\begin{array}{c}0.00 \\
(0.19)^{\mathrm{a}}\end{array}$ & $\begin{array}{c}0.00 \\
(0.19)^{\mathrm{a}}\end{array}$ & $\begin{array}{c}3.33 \\
(10.32)^{\mathrm{a}}\end{array}$ \\
\hline
\end{tabular}

*DpNPV @ $1 \times 10^{9} \mathrm{POB} / \mathrm{ml}$, Mean of three observations,

In a column, means followed by a common letter are not significantly different $(\mathrm{P}=0.05)$ by DMRT

Figures in parentheses are arcsine transformed values

HAT - Hour after treatment

Table.2 Safety of DpNPV formulation and suspension on Bombyx mori

\begin{tabular}{|c|c|c|c|c|}
\hline \multirow[b]{2}{*}{ S.No } & \multirow[b]{2}{*}{ Parameters } & \multicolumn{3}{|c|}{ Treatments** } \\
\hline & & $\begin{array}{c}D p N P V * \\
\text { Formulation }\end{array}$ & $\begin{array}{l}\text { DpNPV* } \\
\text { Suspension }\end{array}$ & Control \\
\hline 1. & $\begin{array}{l}\text { Larval weight (g) at } \\
\text { instar III }\end{array}$ & $0.414 \pm 0.005$ & $0.412 \pm 0.005$ & $0.427 \pm 0.013$ \\
\hline 2. & $\begin{array}{l}\text { Larval weight (g) at } \\
\text { instar IV }\end{array}$ & $1.502 \pm 0.025$ & $1.492 \pm 0.031$ & $1.553 \pm 0.026$ \\
\hline 3. & $\begin{array}{l}\text { Larval weight (g) at } \\
\text { instar V }\end{array}$ & $3.224 \pm 0.056$ & $3.185 \pm 0.044$ & $3.273 \pm 0.021$ \\
\hline 4. & Larval mortality (\%) & $12.143 \pm 1.010$ & $11.428 \pm 0.922$ & $10.714 \pm 0.714$ \\
\hline 5. & Pupation (\%) & $82.143 \pm 1.056$ & $81.714 \pm 0.565$ & $83.571 \pm 0.481$ \\
\hline 6. & Pupal period (days) & $10.571 \pm 0.297$ & $10.857 \pm 0.261$ & $10.714 \pm 0.184$ \\
\hline 7. & Adult emergence (\%) & $90.000 \pm 0.488$ & $90.143 \pm 0.459$ & $91.286 \pm 0.421$ \\
\hline 8. & Cocoon weight (g) & $1.683 \pm 0.020$ & $1.666 \pm 0.021$ & $1.715 \pm 0.012$ \\
\hline 9. & Shell weight (g) & $0.361 \pm 0.007$ & $0.357 \pm 0.010$ & $0.358 \pm 0.008$ \\
\hline
\end{tabular}

${ }^{*} D p N P V @ 1 \times 10^{9} \mathrm{POB} / \mathrm{ml} ;{ }^{* *}$ Differences between means were not significant $(\mathrm{P}=0.05)$ by DMRT 
Table.3 Safety of D $p$ NPV and its formulations to honey bee - Apis cerana indica

\begin{tabular}{|c|c|c|c|c|c|c|}
\hline \multirow[t]{2}{*}{ Species } & \multirow[t]{2}{*}{ Treatments } & \multicolumn{4}{|c|}{$\begin{array}{l}\text { Per cent bee mortality } \\
\text { (days after feeding) }\end{array}$} & \multirow{2}{*}{$\begin{array}{c}\text { Mean number } \\
\text { of days } \\
\text { survived }\end{array}$} \\
\hline & & $5 *$ & 10 & 15 & 20 & \\
\hline \multirow{6}{*}{$\begin{array}{l}\text { Apisceran } \\
\text { aindica }\end{array}$} & $\begin{array}{l}D p N^{*} *+\text { Starch } 10 \%+\text { Tinopal } \\
0.2 \%+\text { Tween } 80(1 \%)\end{array}$ & $46.67^{b}$ & 66.67 & 93.33 & 100.0 & $11.50 \pm 0.29^{\mathrm{a}}$ \\
\hline & $\begin{array}{l}D p N P V *+\text { Sucrose } 10 \%+\text { Tinopal } \\
0.2 \%+\text { Tween } 80(1 \%)\end{array}$ & $43.33^{\mathrm{a}}$ & 66.67 & 96.67 & 100.0 & $11.00 \pm 0.41^{\mathrm{a}}$ \\
\hline & $\begin{array}{l}D p \mathrm{NPV}^{*}+\text { Glycerol } 10 \%+\text { Tinopal } \\
0.2 \%+\text { Tween } 80(1 \%)\end{array}$ & $40.42^{\mathrm{a}}$ & 62.47 & 96.77 & 100.0 & $11.00 \pm 0.41^{\mathrm{a}}$ \\
\hline & $D p \mathrm{NPV}^{*}$ & $43.93^{\mathrm{a}}$ & 65.67 & 96.07 & 100.0 & $11.00 \pm 0.41^{\mathrm{a}}$ \\
\hline & Dichlorvos76EC $0.2 \%$ & $100.0^{\mathrm{c}}$ & - & - & - & $0.75 \pm 0.25^{b}$ \\
\hline & Control & $43.33^{\mathrm{a}}$ & 63.33 & 96.67 & 100.0 & $11.75 \pm 0.48^{\mathrm{a}}$ \\
\hline
\end{tabular}

"In a column, means followed by similar letters are not significantly different $(\mathrm{P}=0.05)$ by DMRT.

*DpNPV@ 1x10 $\mathrm{POB} / \mathrm{ml}$

Table.4 Safety of D $p$ NPV and its formulations to honey bee - Apis mellifera

\begin{tabular}{|c|c|c|c|c|c|c|}
\hline \multirow{2}{*}{ Species } & \multirow{2}{*}{ Treatments } & \multicolumn{4}{|c|}{$\begin{array}{l}\text { Per cent bee mortality } \\
\text { (days after feeding) }\end{array}$} & \multirow{2}{*}{$\begin{array}{c}\text { Mean number } \\
\text { of days } \\
\text { survived * }\end{array}$} \\
\hline & & $5^{*}$ & 10 & 15 & 20 & \\
\hline \multirow{6}{*}{$\begin{array}{l}\text { Apismellif } \\
\quad \text { era }\end{array}$} & $\begin{array}{l}D p \mathrm{NPV}^{*}+\text { Starch } 10 \%+\text { Tinopal } \\
0.2 \%+\text { Tween } 80(1 \%)\end{array}$ & $23.33^{b}$ & 46.67 & 83.33 & 96.67 & $16.25 \pm 0.25^{\mathrm{a}}$ \\
\hline & $\begin{array}{l}D p N^{*} *+\text { Sucrose } 10 \%+\text { Tinopal } \\
0.2 \%+\text { Tween } 80(1 \%)\end{array}$ & $20.00^{\mathrm{a}}$ & 50.00 & 86.67 & 100.0 & $16.75 \pm 0.48^{a}$ \\
\hline & $\begin{array}{l}D p \mathrm{NPV}^{*}+\text { Glycerol } 10 \%+\text { Tinopal } \\
0.2 \%+\text { Tween } 80(1 \%)\end{array}$ & $19.50^{\mathrm{a}}$ & 51.00 & 87.67 & 100.0 & $16.75 \pm 0.48^{\mathrm{a}}$ \\
\hline & $D p \mathrm{NPV}^{*}$ & $19.50^{\mathrm{a}}$ & 51.00 & 87.67 & 100.0 & $16.75 \pm 0.48^{\mathrm{a}}$ \\
\hline & Dichlorvos76EC $0.2 \%$ & $100.0^{\mathrm{c}}$ & - & - & - & $1.25 \pm 0.25^{b}$ \\
\hline & Control & $20.00^{\mathrm{a}}$ & 46.67 & 86.67 & 96.67 & $17.25 \pm 0.25^{\mathrm{a}}$ \\
\hline
\end{tabular}

* In a column, means followed by similar letters are not significantly different $(\mathrm{P}=0.05)$ by DMRT.

*DpNPV@1x10 $90 B / \mathrm{ml}$ 
Table.5 Safety of D $p$ NPV and its formulations to honey bee - Apis florea

\begin{tabular}{|c|c|c|c|c|c|c|}
\hline \multirow{2}{*}{ Species } & \multirow{2}{*}{ Treatments } & \multicolumn{4}{|c|}{$\begin{array}{l}\text { Per cent bee mortality } \\
\text { (days after feeding) }\end{array}$} & \multirow{2}{*}{$\begin{array}{c}\text { Mean } \\
\text { number of } \\
\text { days survived }\end{array}$} \\
\hline & & $5 *$ & 10 & 15 & 20 & \\
\hline \multirow{6}{*}{$\begin{array}{l}\text { Apis } \\
\text { florea }\end{array}$} & $\begin{array}{l}D p \mathrm{NPV}^{*}+\text { Starch } 10 \%+\text { Tinopal } \\
0.2 \%+\text { Tween } 80(1 \%)\end{array}$ & $56.67^{b}$ & 93.33 & 100.0 & - & $8.75 \pm 0.25^{a}$ \\
\hline & $\begin{array}{l}D p N P V *+\text { Sucrose } 10 \%+\text { Tinopal } \\
0.2 \%+\text { Tween } 80(1 \%)\end{array}$ & $53.33^{\mathrm{a}}$ & 93.33 & 100.0 & - & $8.50 \pm 0.29^{a}$ \\
\hline & $\begin{array}{l}D p \mathrm{NPV}^{*}+\text { Glycerol } 10 \%+\text { Tinopal } \\
0.2 \%+\text { Tween } 80(1 \%)\end{array}$ & $52.33^{a}$ & 93.33 & 100.0 & - & $8.50 \pm 0.29^{\mathrm{a}}$ \\
\hline & $D p \mathrm{NPV}^{*}$ & $52.70^{\mathrm{a}}$ & 94.0 & 100.0 & - & $8.50 \pm 0.29^{a}$ \\
\hline & Dichlorvos76EC $0.2 \%$ & $100.0^{c}$ & - & - & - & $0.50 \pm 0.29^{b}$ \\
\hline & Control & $56.67^{\mathrm{a}}$ & 96.67 & 100.0 & - & $9.00 \pm 0.41^{\mathrm{a}}$ \\
\hline
\end{tabular}

In a column, means followed by similar letters are not significantly different $(\mathrm{P}=0.05)$ by DMRT.

*DpNPV@1x109 POB/ml

Fig.1 Safety of D $p$ NPV and its formulation on Trichogramma chilonis Ishii

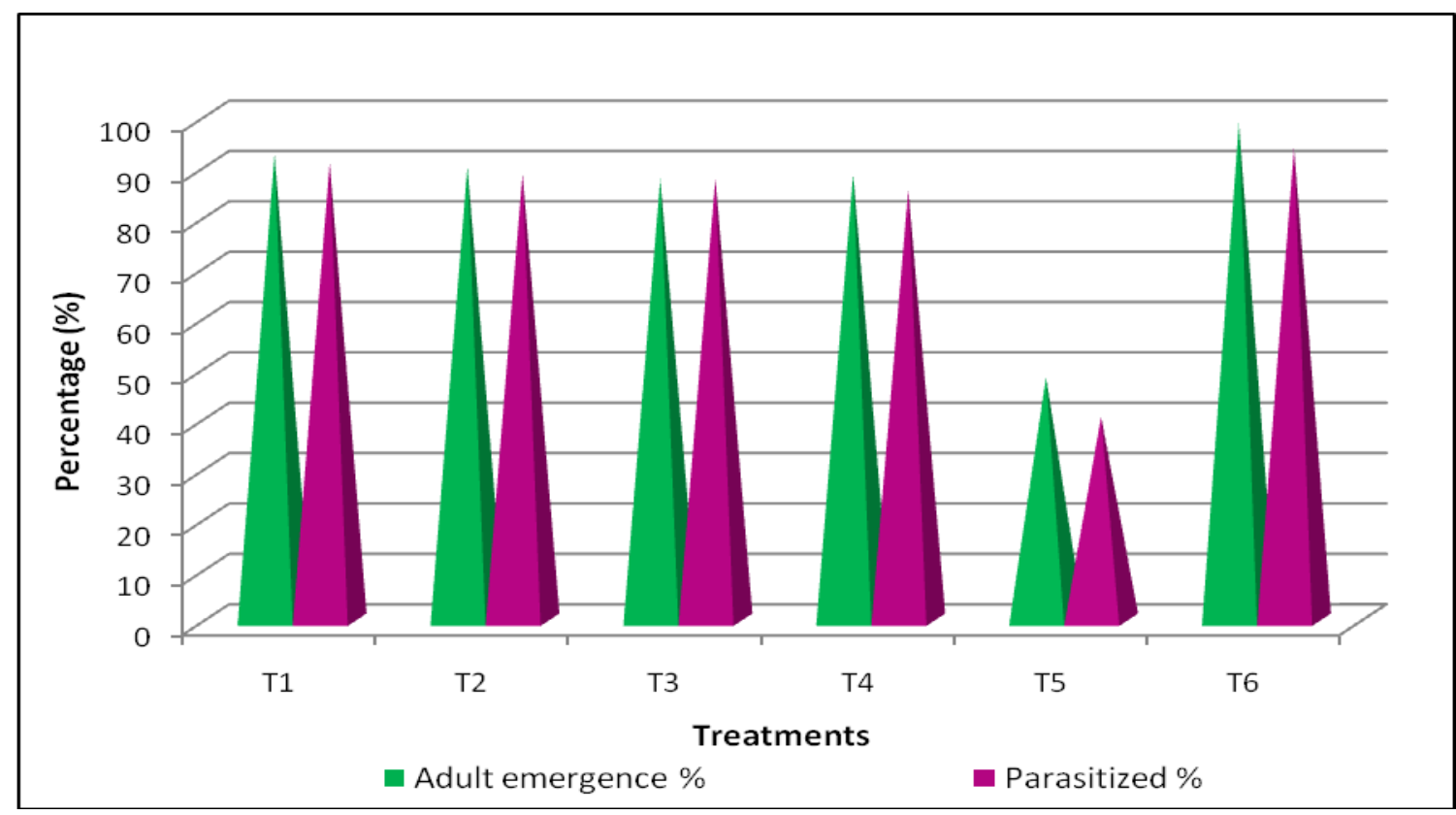

T1- DpNPV $1 \times 10^{9} \mathrm{POB} / \mathrm{ml}+$ Starch $10 \%+$ Tinopal $0.2 \%+$ Tween $801 \%$

T2- DpNPV $1 \times 10^{9} \mathrm{POB} / \mathrm{ml}+$ Sucrose $10 \%+$ Tinopal $0.2 \%+$ Tween $801 \%$

T3- DpNPV1 $10^{9} \mathrm{POB} / \mathrm{ml}+$ Glycerol $10 \%$ + Tinopal $0.2 \%+$ Tween $801 \%$

T4- $D p N P V 1 \times 10^{9} \mathrm{POB} / \mathrm{ml}$

T5- Dichlorvos 76EC 0.2\%

T6- Untreated check 
Fig.2 Safety of D $p$ NPV and its formulation to Chrysoperla carnea Stephens

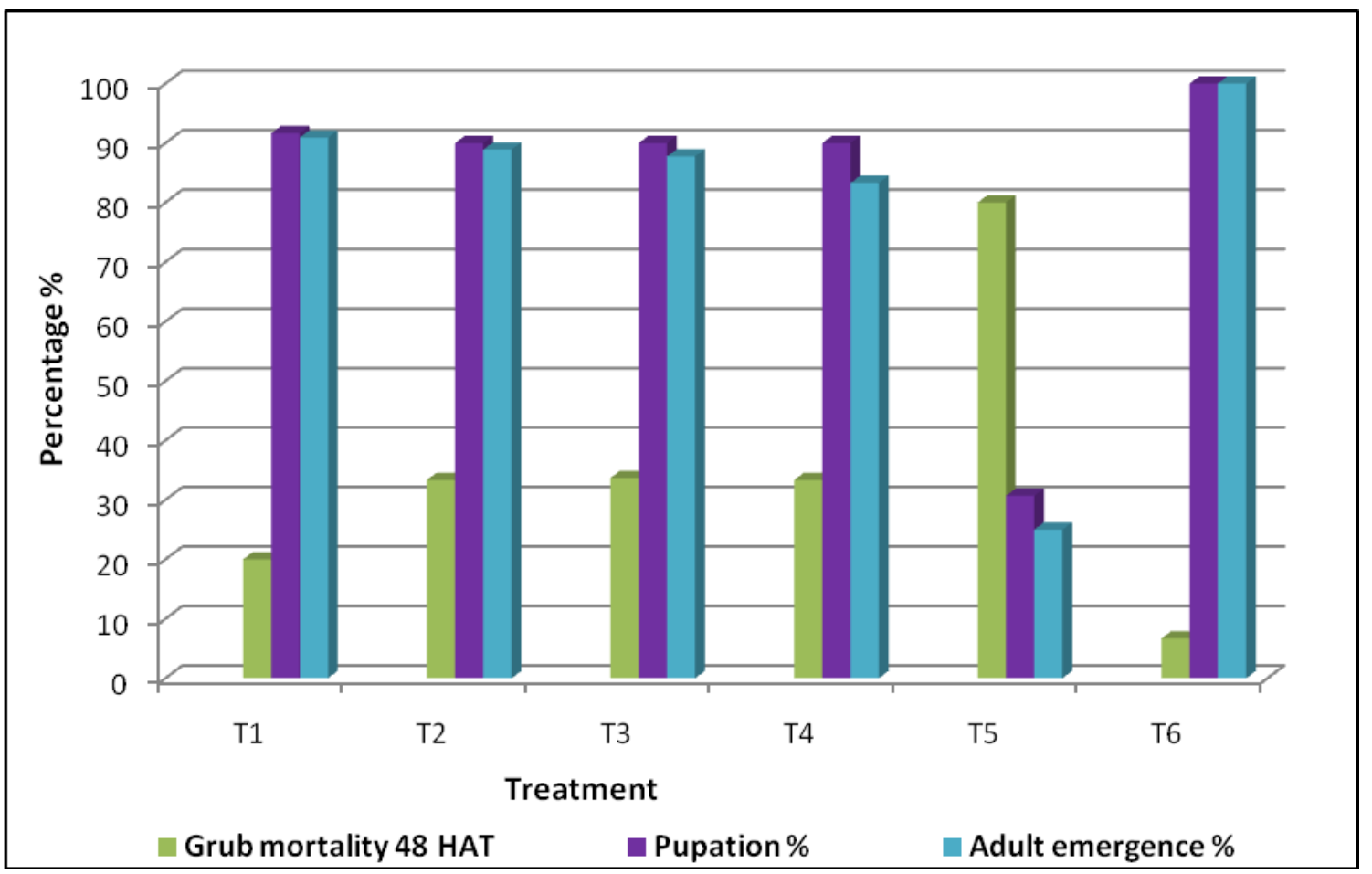

T1- $D p$ NPV $1 \times 10^{9} \mathrm{POB} / \mathrm{ml}+$ Starch $10 \%+$ Tinopal $0.2 \%$ + Tween $801 \%$

T2- $D p N P V 1 \times 10^{9} \mathrm{POB} / \mathrm{ml}+$ Sucrose $10 \%+$ Tinopal $0.2 \%$ + Tween80 $1 \%$

T3- $D p N P V 1 \times 10^{9} \mathrm{POB} / \mathrm{ml}+$ Glycerol $10 \%$ + Tinopal 0.2\% + Tween80 1\%

T4- $D p N P V 1 \times 10^{9} \mathrm{POB} / \mathrm{ml}$

T5- Dichlorvos 76EC 0.2\%

T6- Untreated check

\section{Honeybees}

The $D p N P V$ and its formulations did not show any harmful effect in terms of longevity of various honey bee species (Tables 3, 4 and 5). No changes in the behaviour of the bees were noticed in the adults fed with NPV in sugar solution. While, honey bees fed with dichlorvos in sugar solution caused 100 per cent mortality of the bees within two days. The safety of viruses to honey bees was reported earlier by Dhaduti and Mathad (1980), Santharam et al., (1982), Muthiah (1988) and Parthasarathy (2002). The NPV of Mamestra brassicae had no harmful effect on the honeybees (Groner et al.,
1978). Nomuraea rileyi (Farlow) Samson was found to be safe to the larval parasitoid, Microplitis maculipennis Szep and honey bee, Apis cerana indica Fab., in the laboratory studies (Mulimani and Kulkarni, 2004). No significant changes in the behaviour of the caged bees were observed both in treated and untreated adults. Results of the present investigations revealed the safety of $D p$ NPV and its formulations to B. mori and honey bees and hence could be integrated in biointensive pest management programmes.

In conclusion, studies undertaken revealed that formulated $D p$ NPV showed effective control of mulberry leaf webber compared to 
$D p N P V \quad$ suspension under laboratory condition and also exhibited safety to nontarget organisms viz., T. chilonis, C. carnea, $B$. mori and $A$. indica, A. mellifera and $A$. florea and it could be used as a safe biopesticide in mulberry ecosystem.

\section{Acknowledgement}

The senior author sincerely acknowledges the Rajiv Gandhi National Fellowship (RGNF) for the financial support in the form of Senior research fellowship for his Ph.D. research. Thanks are also due to the Head and Chairman for providing field and laboratory facilities at the Department of Sericulture, Tamil Nadu Agricultural University, during the course of this investigation.

\section{References}

Amin, A. A., M. M. Khattab., M. A. K. ElSheikh and S. El-Salamony. 2005. Screening of four lignin additives as UV protectants to baculovirus (Cotton Insect Research and Cont. Conference), Beltwide Cotton Conference: 1308-1309.

Arivudainambi, S., V. Selvanarayanan and A. Vikash. 2000. Enhancing the efficacy and persistency of Spodoptera litura (Fab.) nuclear polyhedrosis virus using UV irradiation protectants. Indian J Exp. Biol, 38: 1175-1176.

Balasubramanian, G., P. C. Sundarababu and T. R. Manjula. 2001. Efficacy of Bacillus thuringiensis vargalleriae formulation (Spicturin ${ }^{\circledR}$ ) against Helicoverpa armigera (Hub.) on chickpea (Cicer arietinum L.). Madras Agric. J, 88: 336338.

Blissard, G. W., B. Black, N. Crook, B. A. Keddie, R. Posse, G. F. Rohrmann, D. A. Theilmann and L. Volkman. 2000. Family Baculovirdae. (M. H. V. Van Regenmortel et al., Eds.), Virus taxonomy: seventh report of the International Committee on Taxonomy of Viruses. Academic Press, San Diego, Calif. pp.195-
202.

Boomathi, N., P. Sivasubramanian, S. Raguraman and K. Premalatha. 2005. Safety of botanical and microbial pesticide mixtures to Trichogramma chilonis Ishii (Hymenoptera: Trichogrammatidae). J. Biol. Control,19: 23-28.

Burand, J. P. and J. E. Park. 1992. Effect of nuclear polyhedrosis virus infection on the development and pupation of gypsy moth larvae. J. InvertebrPathol, 60: 171-175.

Chen, J. X., Y. G. Ding, D. J. Xu and D. F. Zhang. 1992. Studies on a granulosis virus of the tea bunch caterpillar Andraca bipunctata(Bombycidae) and its utilization. Chiense J. Biol. Control, 8: $72-76$.

Dent, D. and N. E. Jenkins. 2000. Microbial pesticides in augmentative control. In augmentative biocontrol: proceedings of the ICAR-CABI workshop ( $\mathrm{S} P$ Singh, S T Murphy and C R Ballal Eds.) Bangalore, Karnataka, India.

Dhaduti, S. G. and S. B. Mathad. 1980. Effect of nuclear polyhedrosis virus of the armyworm Mythimna separata on colonies of Apis cerana indica. J. Apicul. Res, 19: $77-78$.

Easwaramoorthy, S. and S. Jayaraj. 1988. Effect of two granulosis viruses on the silkworms, Bombyx mori meridionalis F. and Philosamiaricini B. Entomon, 13: 57-59.

Ethiraju, S. 1986. Studies on the development of formulations of Heliothis armigera (Hbn.) and Spodoptera litura (F.) nuclear polyhedrosis virus. M.Sc. (Ag.) Thesis, Tamil Nadu Agric. Univ., Coimbatore, India, p76.

Fauquet, C. M., M. A. Mayo, J. Maniloff, U. Desselberger and L. A. Ball. 2004. Virus Taxonomy, VII report of the ICTV. Elsevier/Academic press, London pp.1258.

Geetha, N. 1997.Studies on genetic variability and development of improved formulations of nuclear polyhedrosis virus of Helicoverpa armigera (Hubner). 
Ph.D. Thesis, Tamil Nadu Agric. Univ, Coimbatore.p.84.

Groner, A. J. Huber, A. Krieg and W. Pinsdorf. 1978. Tests of two baculovirus preparation on honey bees. Nachrichtenblatt-desDeutschen-Pflanzen-schutzdienstes,30(3): 39-41.

Heinz, K. M., B. F. McCutchen, R. Herrman, M. P. Parrella and B. D. Hammock. 1995. Direct effects of recombinant nuclear polyhedrosis viruses on selected nontarget organisms. J. Econ. Entomol, 88: 259-264.

Jeyarani, S., N. Karuppuchamy, N. Sathaiah and S. Manimegalai. 2008. Safety of UV-selected Helicoverpa armigera nucleopolyhedrovirus to non-target beneficial organisms. Journal of Biological Control,22: 107-112.

Kondo, A., M. Yamamoto, S. Takashi and S. Maeda. 1994. Isolation and characterization of nuclear polyhedrosis viruses from the beet armyworm, Spodoptera exigua (Lepidoptera: Noctuidae) found in Shiga, Japan. Appl. Entomol. Zool, 29: 105-111.

Kuppusamy, S. 1994. Investigations on the granulosis virus disease of Heliothis armigera (Hubner) and its use in microbial control. Unpublished M.Sc.(Ag.) Thesis, Tamil Nadu Agric. Univ., Coimbatore, India.p.132.

Lasa, R., C. Ruiz-Portero, M. D. Alcazar, J. E. Belda, P. Caballero and T. Williams. 2007. Efficacy of optical brightener formulations of Spodoptera exigua multiple nucleopolyhedrosis (SeMNPV) as a biological insecticide in green houses in Southern Spain. Biol. Control, 40: 8996.

Lasa, R., T. Williams and P. Caballero. 2009. The attractiveness of phagostimulant formulations of a nucleopolyhedrosis based insecticide depends on prior insect diet. J. Pest. Sci., 82: 247-250.

MaheshBabu, S. 1991. Studies on the efficacy of Heliothisarmigera(Hub.) nuclear polyhedrosis virus and its safety to certain non-target species. M.Sc.(Ag.) Thesis,
Tamil
Nadu
Agric
Univ.,
Coimbatore.p.28.

Mahiba Helen, S., V. V. Sudheendrakumar, T. V. Sajeev and R. A. Deshmuk. 2012. Biosafety of crude and formulated Hyblaeapuera (Cramer) (Lepidoptera: Hyblaeidae), Nucleopolyherovirus (HpNPV) against silkworm Bombyx mori (L.), Indian mynah, Acridotherus tristis (Linn.) and cell lines. Journal of Biopesticide, 5(2): 201-207.

Mehrvar, A., R. J. Rabindra, K. Veenakumari.and G. B. Narabenchi. 2008. Evaluation of adjuvants for increased efficacy of Hear NPV against Helicoverpa armigera (Hubner) using sunset machine. J. Biol. Sci, 8(3): 534541.

Mulimani, V. and A. Kulkarni. 2004. Evaluation of safety of Nomuraea rileyi(Farlow) Samson to larval parasitoid, Microplitis maculipennis Szepl. and honeybee, Apis cerana indica Fabricius. J. Biol. Control,18: 85-86.

Muthaiah, L. 1988. Studies on the nuclear polyhedrosis virus of Heliothis armigera (Hub.) and its formulations. M.Sc. (Ag.)Thesis, Tamil Nadu Agric. Univ, Coimbatore.

Muthiah, C. and R. J. Rabindra. 1991. Control of gram pod borer (Heliothis armigera) on pigeonpea (Cajanus cajan) with controlled droplet application of nuclear polyhedrosis virus and effect of oral feeding of virus on mulberry silkworm (Bombyx mori). Indian J. Agric. Sci, 61: 449-452.

Muthuswami, M., R. J. Rabindra and S. Jayaraj. 1994. Evaluation of certain adjuvants as phagostimulants and UV protectants of nuclear polyhedrosis virus of Helicoverpa armigera (Hbn.). J. Biol. Control,8: 2733.

Parthasarathy, P. 2002. Evaluation of baculoviruses for the management of diamond back moth, Plutellaxylostella. Ph.D. Thesis, Tamil Nadu Agric. Univ, Coimbatore, India.p.154.

Priyadharshini, P. 2009. Molecular 
characterization of NPV of Diaphania pulverulentalis (Hampson) and establishment of phylogenetic relationship with other lepidopteran baculoviruses.Ph.D Thesis, University of Agricultural Sciences, Banglore, $\mathrm{p} 88$.

Rabindra, R. J. and S. Jayaraj. 1995. Management of Helicoverpa armigera with nuclear polyhedrosis virus on cotton usng different spray equipment and adjuvants.

J. Biol. Conrtol,9: 34- 36.

Rabindra, R.J. and S. Jayaraj. 2005. Effect of nuclear polyhedrosis infection on the insecticide susceptibility on Helicoverpa armigeraand Spodopteralituralarvae. $J$. Biol. Control, 4: 31-34.

Ranga Rao, G. V., V. Visalakshmi, M. Suganthy, P. Vasudeva Reddy, Y. V. R. Reddy and V. Rameshwar Rao. 2008. Relative toxicity of neem on natural enemies associated with chickpea ecosystem: A case study. International Journal of Tropical Insect Science,27: 229-235.

Sairabanu, B. 2000.Microbial control of Plutellaxylostella(Linn.) (Lepidoptera: Plutellidae). Unpublished Ph.DThesis.Tamil Nadu Agricultural
University, Coimbatore.pp.136.

Sajap, A. S., M. A. Bakir, H. A. Kadir and N. A. Samad. 2007. Effect of $\mathrm{pH}$, rearing temperature and sunlight on infectivity of Malaysian isolate of nucleopolyhedrovirus to larvae of Spodopteralitura (Lepidoptera: Noctuidae). Int. J Trop. Insect Sci, 27: 108-113.

Sajap, A. S., M. A. Bakir, H. A. Kadir and N. A. Samad. 2009. Efficacy of selected adjuvants for protecting Spodopteralituranucleopolyhedrovirus from sunlight inactivation. J. Asia-Pacific Entomol, 12: 85-88.

Santharam, G., A. AzeezBasha and M. Balasubramanian. 1982. Lack of susceptibility of honey bees to three insect viruses. Indian Bee Journal,44: 35.

Subramanian, S. 1998. Studies on the nuclear polyhedrosis virus of Spodoptera litura (Fabricius).Unpubl. M.Sc. (Ag.) Thesis, Tamil Nadu Agric. Univ., Coimbatore, India.p. 112.

Thennarasan, M. 1997. Studies on the development of oil formulations of nuclear polyhedrosisvirus of Helicoverpa armigera (Hubner). M.Sc. Thesis, Tamil Nadu Agric. Univ, Coimbatore.

\section{How to cite this article:}

Prabhu, S., C.A. Mahalingam and Krishnamoorthy, S.V. 2017. Safety Studies of DpNPV (Diaphania pulverulentalis Nuclearpolyhedrosis Virus) Suspension and its Formulation on Non-Target Organisms in Mulberry Ecosystem. Int.J.Curr.Microbiol.App.Sci. 6(6): 1903-1913. doi: https://doi.org/10.20546/ijcmas.2017.606.223 